\title{
BUSINESS MODEL OF NON-GOVERNMENTAL ORGANIZATIONS FOR THE DEVELOPMENT OF THE EDUCATION SECTOR IN MOZAMBIQUE: A CONSTRUCTIVIST APPROACH
}

\begin{abstract}
PEDRO CABRITA
pncabrita@gmail.com

Independent researcher (Portugal) focused on the problematic of organizational development in Africa, particularly in Lusophone Africa. He has a master's in development studies from the School of Social and Human Sciences of ISCTE-Instituto Universitário de Lisboa and bachelor in management from Universidade Autónoma de Lisboa
\end{abstract}

RENATO PEREIRA

renato.pereira@iscte-iul.pt

Professor of General Management at ISCTE Business School, ISCTE-Instituto Universitário de Lisboa. Researcher at the Business Research Unit (ISCTE-IUL, Portugal) the Observatory of Foreign Relations (Universidade Autónoma de Lisboa) and the Emerging Markets Research Center (ISCIM, Maputo). Also, PhD in management sciences, Université Paris Dauphine

MAOMEDE NAGUIB OMAR manotio@yahoo.com.br

Post-doctorate fellow and researcher at OBSERVARE-UAL; associate professor at ISCIM-Instituto Superior de Comunicação e Imagem de Moçambique (Mozambique) and researcher at the Emerging Markets Research Center. Also, PhD in higher education studies and master's in public management, both from the University of Aveiro, as well as apost-graduate from the University of Witwatersrand

\section{Abstract}

This research aims to determine the business model of non-governmental development organizations (NGDOs) of the education sector in Mozambique. The work adopts a constructivist methodological approach in two stages: (i) inductive, centered on the construction of a proposal of social business model Canvas from the observation of 15 NGDOs operating in the education sector in the country, based on a theoretical framework solidly supported in the literature; (ii) deductive, testing the proposed model using a panel technique that allowed the refinement and reconstruction of the proposal initially formulated. The paper contributes to the literature on social business models by making a pioneering validation of knowledge built in this area and in a field of application not yet explored. The contribution to international relations lies at the level of the data collected and information produced on international cooperation in Mozambique.

\section{Keywords}

International cooperation, Mozambique, canvas social business model, NGDOs, Education

How to cite this article

Cabrita, Pedro; Pereira, Renato; Omar, Maomede Naguib (2021). Business model of NonGovernamental Organizations for the development of the education sector in Mozambique: a construtivist approach. Vol12, No. 2, November 2021-April 2022. Consulted [online] on the date of the last visit, https://doi.org/10.26619/1647-7251.12.2.9

Article received on June 16, 2021 and accepted for publication on September 8, 2021

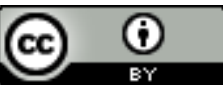




\title{
BUSINESS MODEL OF NON-GOVERNMENTAL ORGANIZATIONS FOR THE DEVELOPMENT OF THE EDUCATION SECTOR IN MOZAMBIQUE: A CONSTRUCTIVIST APPROACH ${ }^{1}$
}

\author{
PEDRO CABRITA
}

RENATO PEREIRA

MAOMEDE NAGUIB OMAR

\section{Introduction}

Non-Governmental Development Organisations (NGDOs) play an increasingly important role in Africa because, among other reasons, the recent Covid-19 pandemic and accelerated population growth raise challenges that are difficult to address only with the intervention of traditional actors - state, families, and businesses.

The importance of these organizations is particularly noted in Mozambique, one of the countries on the UN's least developed countries list, which has very pronounced shortcomings in structural sectors such as education, health and feeding.

The business model of these organizations is generally difficult to grasp, which makes it difficult to assess the value created by them and the extent of the externalities (positive and negative) generated for Mozambican society.

This research, thus, contributes to the knowledge on this topic by providing a pioneering study on NGDO business models in Mozambique, focused on the education sector.

\section{Literature review}

\section{1. "Third Sector" business}

In Mozambique, in 2015 there were more than 11,000 non-financial institutions, 9\% of which were in the education and research sector, surpassed only by religious $(26 \%)$ and commercial (20\%) organizations. Nevertheless, in terms of expenditure for services provided, non-profit institutions (NPIs) associated with education are the ones with the second highest percentage, being only surpassed by social services. Of this total, only 285 are NGDOs, $53 \%$ of which are national, $32 \%$ are foreign and $15 \%$ are

1 Article translated by Hugo Alves. 
unclassified institutions. 35 were dedicated only to education, occupying the second highest percentage after human health and social action activities. Its presence is most notorious in the provinces of Inhambane, Sofala and Manica, being mostly in municipal areas compared to districts without local authority. The number of organizations of this nature has continuously growth since 1975 , reaching a maximum of 582 . They employ about 17,000 people, mostly men. Compared to other areas, the growth of this segment has been constant, while in other sectorsit varies depending on the time and volume of investment (INE, 2015).

The activity of these social organizations falls under the so-called "third sector". This epithet is due to the terminology of "civil society organizations" (CSOs) that do not fit into the other two business categories (first sector, government; and, second sector, market) (Aveni, 2018; Osborne, 2008).

The third sector is made up of organizations whose mission is to contribute directly and specifically to the welfare of a community in which resources are extremely limited, taking the nature of foundations, associations, religious organizations, cooperatives, among other civil activity organizations created on the initiative of citizens, hence having been called "Non-Governmental Organizations" (Defourny\& Nyssens, 2008). They are active in major public service areas, such as "health, education, culture, human rights, housing, environmental protection, local development, or personal development" (Salvatore, 2004, p. 27).

These organizations contribute to production, distribution, provision of services, assistance, savings, and security in a democratic andcollective way, and associated manner with free initiative and the right to individual freedom. They have created a new concept of economy, called "solidarity economy" for not recognizing the market as an area of operation for their business model (Singer, 2002).

The strategy and structure of these organizations varies widely, and three different cases can be identified. In a first group, we find organizations that have a social mission, and are therefore fully inserted in the solidarity economy. In a second group, we find organizations that operate with two interconnected business models, one oriented to competitive success in the market and another that channels its resources towards social purposes. Finally, we have a third group that has two totally separate businesses and where fundraising is completely autonomous from the social cause and has a purely profitable purpose (Aveni, 2018).

The space of action and the capacity to raise support from public agencies and other entities by these organizations has increased substantially, and theoretical and ideological criticism have emergedin the wake of the criticism of the relationship between capitalism, social inequalities, and poverty (Singer \& Brandt, 1980). With these criticisms, fragmentation also arose by areas of activity, leading to a specialization that did not seek to solve all social problems at the same time (Gohn, 1997).

It is in this context that NGOsin education are beginning to emerge in force, presenting palliative perspectives, change, innovation and political pressure, exposing the gaps of political power regarding the guarantee of access to education. Initially, these were isolated initiatives, with low visibility and little sustainability. However, with the 
improvement of results and the increase of studies and attention from academics, their initiatives have gained importance and social notoriety, although there are also negative impacts (Coutinho, 2004).

According to Freire $(1987,1989,1992)$, the role of these organizations in popular education has been extremely positive. This has given them a role of "protectors" of the populations, which has substantially strengthened their social legitimacy.

With the increasing importance of NGOs and the evolution of the concept of "development", the concept of "NGDOs" (non-governmental organizations for development) emerges, also emerging the need to specify concrete areas of action of these organizations (Calheiros, 2003; Seers, 1969).

The institutionalization of the concept of "development" arises from the need for scientific validation and political-institutional recognition in the post-World War II, for various reasons, the most cited being the independence of the former European colonies and the need to rebuild Europe, both linked to the foundation of accumulation processes, the need to create social order and the convergence of the state's interventionist logics in the economy (Roque-Amaro, 2017).

This concept has become morecomplexwith the theoretical evolution of both Keynesian and Marxist-Leninist inspiration, in the dichotomy capitalism-socialism, which has mobilized politicians and anonymous citizens, strategies and plans, theories and practices. From 1992 on, it will be dubbed "post-development", or beginning of a new era, from the different experiences of industrialization and economic growth, cultural values, and geostrategic interests, finally basing on the logics of inequality and gender domination (Roque-Amaro, 2003).

Just as the discussion around the concept mobilizes different positions and arguments, the projects of non-governmental organizations for development also vary in form, organization, and objectives because of the constant emergence of new problems. The sphere of action of these organizations is divided into three main areas: development cooperation, education for global citizenship, and humanitarian and emergency action (Portuguese NGDO Platform, 2020).

The number of these organizations has been continuously increasing, being accompanied by the expansion of literature related to the subject (Bendell, 2000). This growth has led to the emergence of institutes and foundations to measure, facilitate, and certify their real impacts, as well as to connect the associated and involved parties, such as the government, individuals and collectives, public bodies, and community institutions (Patrocínio, 2020). Recently, one of the qualifications associated with NGDOs that has gained the most importance is that of "OSCIP" (Civil Society Organization of Public Interest) that recognizes them as partners of public authorities (Neto, 2017).

As their importanceincreased, the need to measure the impact of these organizations arose. To this end, performance indicators have been created in monitoring and managing operations and resources and achieving objectives, both to measure the impact of organisations in an individual way and jointly (Lugoboni et al, 2016). Indicators should focus "on a process as systematic and objective as possible, consisting of evaluating a project, programme or policy, its design, implementation and 
results. It is intended to determine the relevance and degree of achievement of the objectives, as well as efficiency, effectiveness, impact, and sustainability in terms of development. An evaluation should provide credible and useful information and allow lessons learned to be incorporated into the decision-making process of beneficiaries and donors"(CICLP, 2014, p.8). It is also necessary to follow a process for evaluation and it is therefore mandatory that indicators are based on recognized formulas to increase their credibility and realism (Cohen \& Franco, 1999).

\subsection{Canvas Business Model and Canvas Social Business Model}

The business model is an intermediate layer between the strategic and operational dimensions of an organization and describes how it creates, delivers, and retainseconomic value (Osterwalder, 2004). Its structure is based on a set of building blocks that allow us to understand how this process occurs (Osterwalder \& Pigneur, 2010).

Osterwalder \& Pigneur (2010) developed the business modeling tool known as "Business Model Canvas",specifically targeting for-profit organizations, based on 9 building blocks: "customer segmentation","value propositions", "channels", "customer relationship", "sources of income", "key resources", "key activities", "key partnerships", and "cost structure".

With the extensive and successful use of this tool, suggestions have emerged to extend its use to non-profit businesses or with social impacts (Resende, 2016). Although Business Model Canvaswas created for all types of businesses aimed at creating value, its use by social organizations implied considerable adaptations (Doherty, 2019).

It was with this concern in mind that we sought to develop a "Social Business Model Canvas". From several advanced proposals (e.g., Agafonow\& Donaldson, 2015; Canestrino et al., 2019; Carayannis, 2021; Czinkota et al., 2020; Gauthier et al., 2020; Maurya, 2010; Sabatier et al., 2017; Sparviero, 2019; Spiess-Knafl et al., 2015; Umar et al., 2020), the Social Entrepreneurship Agency, among others, has been developing and refining a complete Social Business Model Canvas framework (SEA, 2020).

The choice of these building blocks aimed to ensure the following: the validation of the basic idea; the reduction of risks; the obtaining of resources; the reflection on oneself and on its business; the media; and, finally, support for management. This led to the need to contemplate the structure of the business plan through entity history; underlying market; positioning in the market; design concept/idea/product; commercial strategy; management and control of the business; investment required; and their financial projections.

All information must be present in the final table, and it must be accompanied by a visual learning methodology through colors that facilitate the distinction of related areas, with an action plan in 4 stages and groups: the creation of value (green); the value proposition (orange); the delivery of the value (yellow); and capturing and sharing value (blue). In addition to these there is also the Mission of the value (dark grey) and the Externalities of the same (light grey). Finally, the model must be 
accompanied by the explanation of each choice with an accessible and direct languageand, if possible, should mention the timeframe of each objective.

Figure 1 - Representation of the Social Business Model Canvas

\begin{tabular}{|c|c|c|c|c|c|c|}
\hline \multicolumn{6}{|c|}{$\begin{array}{l}\text { Mission } \\
\text { What is the main objective and purpose? This should be the space linked to the organizational and } \\
\text { personal origins and also to present the protagonist decisions and activities supporting the Mission }\end{array}$} & \multirow[b]{2}{*}{$\begin{array}{l}\text { Positive } \\
\text { Externalities } \\
\text { What are the main } \\
\text { benefits and positive } \\
\text { impacts of the } \\
\text { activities performed } \\
\text { by the organization? }\end{array}$} \\
\hline $\begin{array}{l}\text { Problem } \\
\text { What is the group's main } \\
\text { problem and its } \\
\text { perspective? }\end{array}$ & $\begin{array}{l}\text { Key Activities } \\
\text { What are the } \\
\text { key actions to be } \\
\text { taken, to meet } \\
\text { the objectives? }\end{array}$ & \multirow{2}{*}{\multicolumn{2}{|c|}{$\begin{array}{l}\text { Value } \\
\text { Proposition } \\
\text { Through the } \\
\text { delivery of } \\
\text { value to the } \\
\text { target group, } \\
\text { what are the } \\
\text { expected } \\
\text { results? }\end{array}$}} & $\begin{array}{l}\text { Relationship } \\
\text { with the } \\
\text { beneficiaries } \\
\text { Who will } \\
\text { receive the } \\
\text { value } \\
\text { proposition? } \\
\text { What is the } \\
\text { relationship to } \\
\text { be had withthe } \\
\text { target group } \\
\text { and what are } \\
\text { the points to } \\
\text { be taken into } \\
\text { account? }\end{array}$ & $\begin{array}{l}\text { Relationship with } \\
\text { Taxpayers } \\
\text { Who can contribute } \\
\text { to the organization } \\
\text { and how to maintain } \\
\text { the relationship } \\
\text { between parties? }\end{array}$ & \\
\hline $\begin{array}{l}\text { Solution } \\
\text { Whatistheproposedsolutio } \\
\text { n to solve } \\
\text { thedetectedproblem ? }\end{array}$ & $\begin{array}{l}\text { Indicators/Res } \\
\text { ults } \\
\text { What are the } \\
\text { indicators that } \\
\text { were chosen to } \\
\text { measure the } \\
\text { impact? Whether } \\
\text { they are social, } \\
\text { political, } \\
\text { environmental } \\
\text { or economic. }\end{array}$ & & & $\begin{array}{l}\text { Channels } \\
\text { How to access } \\
\text { resources and } \\
\text { how to get } \\
\text { them to their } \\
\text { destinations? }\end{array}$ & $\begin{array}{l}\text { Partners } \\
\text { Who are the key } \\
\text { partners that can } \\
\text { contribute to } \\
\text { success? }\end{array}$ & \multirow[t]{2}{*}{$\begin{array}{l}\text { Negative } \\
\text { Externalities } \\
\text { What are the side } \\
\text { effects on the target } \\
\text { group and third } \\
\text { parties? How to } \\
\text { mitigate these. }\end{array}$} \\
\hline \multicolumn{3}{|c|}{$\begin{array}{l}\text { Cost Structure } \\
\text { What are the main costs to be taken into account in } \\
\text { the strategic elaboration of the plans? }\end{array}$} & \multicolumn{3}{|c|}{$\begin{array}{l}\text { Financial Sustainability } \\
\text { What are the budget limits and how do you } \\
\text { keep spending and revenues in balance? }\end{array}$} & \\
\hline
\end{tabular}

Source: Adapted from SEA (2020)

Within THE NGDOs, the approach is tailored according to the target audiences, their activities, relationships, and desired results, so that the organisation concerned competently fulfils its mission. This segmentation is justified by the variety of NGDOs and responses to be made to the different groups and realities of the most diverse development challenges. In addition to the variety of beneficiaries segments, within each of the areas the emergence of new inequalities and barriers to development causes new segments to emerge, accompanied by new approaches and distinguishing factors.

\section{Empirical study}

\subsection{Research methodology}

The objective of this work is to build a business model proposal for NGDOs in the education sector in Mozambique. Considering that a study of this nature had never 
been carried out in this country before, we formulated the following research questionsq: How is the(social) business model of Mozambican NGDOs in the education sector characterized? Does the use of the Social Business Model Canvas tool allowyou to describe this business model?

To answer these questions, we divided empirical work into two stages: (i) an inductive stage, based on observation, analysis, description, and interpretation of the business models of fifteen NGDOs in the education sector working in Mozambique. These organizations were selected based on their approach, results achieved and availability of information. The sample was stratified by size (small, medium and large), regional focus (international, national and local) and also by motivation (political, religious, social, etc.), culminating in the construction of a provisional proposal of a business model representative of the reality studied according to the Framework Social Business Canvas Model (SEA, 2020);(ii) a deductive and confirmatory step, through a focus groupmethodology, in which a carefullyselected panel of observers was invited to assess the provisional proposal, extracting from its feedback elements that allowed the refinement of the model and the submission of a second proposal, empirically supported.

Data analysis, in both stages, was performed through qualitative and quantitative modeling techniques using Microsoft Excel software.

\subsection{Problem and Solution}

The fundamental problem is the lack of access to education in Mozambique. The solution is the availability of resources that can make a difference generating a chain effect that changes not only the availability of education, but all the factors linked to it. However, not all realities have the same problems or the same responsiveness, so the main difference between the studiedNGDOs lies precisely in the different approaches and responses mobilized.

\subsection{Segmentation - Beneficiaries}

With three types of education - formal, non-formal and informal - and various levels of evolution within each, the first challenge for NGDOs in the field of education is the choice of the approach to be followed,considering the existing population, the historical context, the existing conditions, the potential, interests, and the duration of the project.

All fifteen studiedNGDOs made the evaluation process for the decision and chose to create schools with formal education models in isolated places, choosing for this reason segregated populations with difficult access to education and urban centers. Although the Mozambican state provides schools throughout the country, they are not of widespread access and there are no responses for isolated populations.

The type of teaching chosen is formal education because it is the type of education promoted by the Mozambican state. There are, however, differences in the selection of students and trainees for the programs and in the level of education provided. 
In the studiedNGDOs, fourteen of the fifteen have as object early childhood and basic education, one of which focuses only on early childhood education and the other only on basic education. Of the same fourteen, only six have projects with secondary school students, seven with university students and nine with teachers and communities.

Based on the data collected, one can see that the preference goes to the most basic levels. Older individuals have greater obligations to contribute to family support and tend to drop out of school before reaching secondary level. This results in the sustainability of projects due to lack of audience, forcing interested students to send students to other locations with scholarships.

The number of NGDOswith adult and community training shows that there is interest and beneficiaries available. These projects vary in approach and purpose from group to group and locality to locality.

\subsection{Key activities and resources - Beneficiaries}

In the area of education, the key elements are:

- space/rooms;

- teachers/trainers

- students/trainees

- educational/formative content;

- school supplies.

All other necessary resources, such as uniforms, computer devices, toilets, canteen, among others, are not priorities.

In ten of the NGDOs analyzed, it was on their own initiative and using own funds that the space for the classes was created. These spaces end up being multipurpose, allowing community meetings, temporary health posts, among others.

Teachers/trainers are usually Mozambicans. The students are mostly localsof the area where the classes take place and the peripheries of these localities. When significant travel is required, networks are created between communities to ensure the safety of the student. In this study, three of the NGDOs had this network created. There is rarely a refusal of students, even when headcount far exceeds maximum capacity.

The contents taught are official and defined by the government. These programmes are generally adapted to the local reality, atthe level oflanguage, practices, andcustoms, to enhance the adoption and results. Depending on the level of education and the NGDOs approach, local crafts are also taught to fix populations and increase the impact on local development.

Most projects take place in isolated areas where there is no access to school supplies. Therefore, they must be bought elsewhere, eventually coming directly from abroad. 
In view of the deep needs of the populations in which they are included, NGDOs end up developing other activities in key areas such as health, nutrition, water, community participation, technological innovation, services, and the environment.

The organizations analyzed have activities in three different areas, in addition to education, and only one of them has some participation in only one extra area and a single organization participates in all other areas.

They all have community projects, focusing on an integrated approach to development. Health is the second emphasis of care, focusing on the action in the education of healthy practices, medical examinations, and availability of medications. Then we find the concern for the lack of nutrition and water, under the maxim that "a hungry student does not learn", materialized by the availability of meals in school that for many represents the only hot meal they have during the day.

Finally, in the two least participated areas we find technological innovation and services (eight) and the environment (four). It should be noted that there is no standardized relationship between the size of NGDOs and their presence in different areas, and that seems more like a strategic option issue.

Summing up all the projects of all NGDOs, we have a total of seventy-two in education, with a maximum of fifteen and a minimum of only one per organization. Unlike extra activities, in education activities the dimension is critical. BigNGDOs have a larger and more decentralized area of activity, with fifteen projects taking place simultaneously in fifteen different locations. Small ones, however, usually have more than one project at the same time, focus on the same location for synergies of Results/Impacts.

\subsection{Channels}

Since channels are the way to connect the parties considering key activities and resources, one can strategically define the following 3: communication, distribution, sales, and donations.

Starting with the communication channel, the goal is to present and make known what has been and will be done to strengthen or create relationships with the target associates, while disseminating relevant information. This communication has an internal and an external component:

- Internal communication - between the participants of the organization. The main result is the account and activity report where the results of internal activities are disclosed.

- External communication - with civil society, with beneficiaries and taxpayers.

In our sample, only four of the fifteen chose to subcontract the communication. All NGDOsthat were studied have accounts on social networks (Facebook, Instagram, Twitter, LinkedIn, among others), a website and a newsletter. On all these platforms thereare links to the website. These tend to be transparent in their content, easy to navigate and oriented to attract potential supporters of the cause, be they associates, 
donors, volunteers, or partners. Many even include a blog or news wall. Newslettersvaryfrom monthly, quarterly, semiannual, and yearly. They are almost all digital and delivered by email. Four of the organizations deliver paper magazines, letters, and bulletins.

In addition to these, there are other communication channels such as television, telephone and radio, the latter being only used by one of them. Based on our data collection it is possible to state that although there are investments in communication, they are mostly reduced and are not used in a differentiating way.

As for distribution channels, these are used, in most cases, for both the main activity and the secondary activities. Regarding the main activity, the school materials of both pupils and teachers are concerned and may also include other assets. There are three main origins: the localities themselves (six of fifteen), other national localities (fourteen of fifteen) or foreign (twelve of fifteen). Local distribution is common in projects that have been on the ground for the longest time, revealing that distribution channels evolve over time. As for the other two origins, the exchanges are greater at national level, except in a case that favors foreigners.

Finally, in sales channels and donations it is possible to detect a pattern in the type of contact because all privilege electronic communication with their donors, partners, and customers, including digital signing of contracts, receipt of contributions by bank transfer and communications/meetings on virtual platforms. As for physical contact, twelve NGDOs, do so to deepen the relationship between the parties, using dynamics of active participation, dissemination of data and holding face-to-face events. The three that do not, receive their financial contributions almost exclusively from the same sources of funding.

\subsection{Relationship with beneficiaries}

Knowing the needs and constraints of the beneficiaries, it is possible not only to define the strategy of implementation of the project, but also the monitoring of its participants:

- A priori - Before the implementation of the projects, their leaders went to the localities to check the interest of potential students and family members, study their culture, raise needs, define objectives, and prepare an initial proposal. In most cases, formal or formal agreements have been made with local community leaders and education leaders to ensure the commitment of the various parties.

- During - It was identified that some of the projects have no deadline and others have only a generic one (e.g., last quarter of year X, or when another objective is reached). This makes the evaluation during crucial, focusing on the relationship with beneficiaries by measuring levels of school interest and adapting to needs. The focus is as much on the result as on the adhesion of students, teachers, and the community where the project is inserted, since without themit will hardly be successful. 
- posteriori - Reaching the end of the project cycle, it is necessary to measure its level of achievement. In addition, it is required to bridge the gap with future proposals from the same or other organizations.

\subsection{Relationship with customers/contributors}

In the studiedNGDOs, the importance of customers/taxpayers who assume themselves as funders/investors of the organization is linked to the channels of communication and sales/donations. Both parties seek to carry out the interest, the retention of stakeholders and the expansion of the offer, not only to increase the network of contacts but also the value of the raisings, which will increase financial sustainability. To this end, in addition to the use of the communication channel, organisations seek to attract, maintain, and broaden interest as follows:

- Godparents (solidary sponsors)/associates - The raising takes place in two main ways: the indirect, through the information available in the communication channels and the word of mouth among acquaintances of the organization; and direct, in the events of the organization and in tête-à-tête programs. Direct fundraising is considered more effective.

- Donations - Work for those interested in supporting, but without availability or interest in staying associated, that is, without additional commitments or responsibilities. It can be constant or punctual and have as object the most varied type of goods or services. The more specific the donation request, the higher the probability of obtaining a higher value.

- Sales - They are carried out through an independent/autonomous business, but associated with the cause, and the value proposition is the support to education although the usefulness of products and services is different from it.

- Funds and grants - A privileged route to financing non-profit organizations, it is a source that is always at the top of the priorities of NGDOs.

- Events - They are one of the most effective means to achieve the three objectives of the relationship with customers. They allow you to create a hybrid space between formal/informal and exclusive/open. However, they entail increased charges.

Based on the collected data, it is possible to notice that all fifteen NGDOs use donations, twelve of them use funds and grants, and ten have godparents/associates. Of the twelve organizations that receive funds and grants, only eight have at the same time godparents/associates. In other cases, when they do not have solidary sponsors/associates, have funds and subsidies and vice versa, except in a case where it was chosen not to use any of these mechanisms. The organization of events was observed in eight organizations and six of them make sales to customers.

On average, three of these mechanisms are used by each organization, two of which use them all, four of them use four, seven of them use three and two of them only use two. One cannot identify a relationship between the choice of relationship forms and the size of the organization, its origin, or success rate. It is, however, possible to detect 
that when organizations are in the expansion phase, they opt for two main approaches to increase the number of customers/contributors.

The results obtained allow us to conclude that contributions per donation are a source of funding generally used, both for the reasons listed above and for their versatility, easy adaptation to the needs of NGDOsand by the reduced need for commitment. Donations materialize in different ways: money, school supplies, clothing, clothes and even air miles; no dominant pattern has been identified. In addition to the permanent open bank transfer mechanism, many organizations choose specific moments in advance by disclosing the timing of such collections. Another possible means istaxconsignment incountries where it exists, which, despite not reaching significant values, contributes to the public notoriety of the NGDO.

Aid for funds and grants has been growing and showing up as one of the main forms of support for new organisations in need of initial investment. Funds vary in origin, but most are deprived of institutions, foundations, companies, and organizations. There is, however, a significant use of public funds. Most applications are renewed when the fund comes to an end, so it is important to maintain the relationship and show the results and impacts. In the organizations that were analyzed, only one of them uses funds and subsidies in addition to donations, which shows their concern to join civil society.

The use of the concept of godparent/associate is very popular among NGDOsin education. Those receive periodic information about their godchildren, constantly strengthening the bonds between the parties. To have as many solidary sponsors as possible, organizations provide flexible financial contribution schemes. This component is usually not sufficient to sustain project expenditure, forcing organisations to look for complementary forms of funding.

Events have a diversity that is difficult to standardize. They include workshops, training, group activities, meals, play sessions, hiking, among others. There is also a wide variety of results, whether in terms of profits, increased network of associates, dissemination of a given project, among others, regardless of the size of the NGDO or its level of notoriety. In the analyzed sample, five out of eight of those who chose to bet on the events had godparents/associates.

Finally, the option to make associates into clients has been a little used option in the sample that was studied. All NGDOs that do so, have products associated with education and some produced in the localities of the projects or that are traditional in respective areas. Of the six that do as such, only one focuses exclusively on sales as a source of income, in addition to donations. However, they all have a social impact organization model.

\subsection{Cost structure}

Knowing the main and secondary activities, their associated factors, the channels that are used and the specific needs of beneficiaries and taxpayers/customers, it is possible to have a complete view of the costs that the organization will incur in a project. The collected data in this study does not allow to indicate a pattern for the two categories mentioned in the theoretical contextualization (fixed costs and variable costs) or for the 
two structures (economies of scale and economies of scope) due to the lack of information and the various specific approaches and strategies. However, it is possible to mark and relate the main expenses found.

\section{Fixedcosts:}

- Expenseswith project staff - The four main cost centers identified in schools are: teachers, trainers, and educators; the school's attendants and assistants; the cooks (when there is a canteen); and school supplies (including school insurance). In addition to those, there are administrative services and management, as well as coordination, that are ensured as much as possible by local people to strengthen organizational sustainability.

- Expenses with the organization's staff - In addition to the human resources of the projects, there are also people who work in the management of the organization itself. The main functional areas identified are strategy, financing, communication, accounting, human resources, and project management.

- Office supplies - Most workers are associated with the consumption of materials. There is a tendency to make a forecast of these consumptions or even a delimitation of budgetary possibilities to fix these costs.

- Communications - To create a communication channel between projects and the organization it is necessary to develop a safe, stable, and cost-effective approach. Although it is not a reality common to all NGDOs studied, most of them favourinternet for this purpose.

- Leasing - Both in the projects and in the organizations' locations there are associated leases, mainly of equipment and facilities. In the sample that was studied, leasing is justified because itis less costly than the acquisition. It is possible, however, to see that the most common rental cases refer to real estate.

- Services - Unlike the rental of equipment and facilities, in the provision of services there is a balanced division between the expenses of the projects and those of the general administration.

\section{Variablecosts:}

- Energy and water - These costs arise from both basic and superfluous consumption as the utility differs. Much information about them was not found in the NGDOs evaluated.

- Depreciation - Based on the study done, it is possible to detect that this type of cost is reduced compared to the other projects' charges.

- Feeding - In NGDOs that had feeding canteens for their students, costs often vary, making it impossible to classify them as a fixed cost. Nevertheless, in the sample these costs are presented as fixed because an average is made that varies depending on the location and other relevant constraints.

- Other expenses - All other expenses required.

With its costs listed, we can see that fixed costs are more significant than the variables in NGDOsin education, preponderating the economies of scope. At the same time, there 
are economies of scale in exported goods, from clothing to school supplies as well as in food products.

\subsection{Financial sustainability}

Financial sustainability is the NGDO's long-term ability to generate the financial resources that are necessary to develop its strategic purpose. To dothis, it is necessary to ensure that the sources of revenue are sufficient to cover the expenses necessary to carry out strategic planning, accounting, flexibility/adaptability, and vision for the future.

The value and number of sources of income have been increasing in NGDOs, enhancing the emergence and expansion of this type of organizations. Themainsources of resources are as follows:

- Sponsorship fromlegal entities;

- Support from individuals;

- Donations from foundations and international organizations;

- Partnerships with government agencies;

- Consignment of taxes.

\subsection{Main partnerships}

Partnerships have different origins, but the common purpose of optimizing business models, reducing risk, and increasing capabilities. They vary in type and motivation, depending on the specific focus, and can therefore reach different elements of the business model.

The main types are four, having as a common element the win-win logicthat determines the basis of a key partnership:

- Strategic alliances - Partnership between non-competing organizations seeking complementarity;

- "Coopetition" - Cooperation between competing organizations that want to share risks;

- Joint ventures - Joint creation of new temporary businesses, usually to respond to a tender/call, which individually none of them could win;

- Buyer-supplier agreements - Targeting predictable and stable supplies, especially in markets characterized by volatility.

In terms of motivations, one can find four main types: optimization and economy of scale; cost reduction through subcontracting and infrastructure sharing; reducing the risk of uncertainty through partner involvement; and acquisition of resources and private activities, such as know-how, licenses or even investment capacity. 
Partnerships within NGDOs are usually made with a particular focus. In addition to the association with small entities and individuals, there is growing concern about the impact of involvement with large companies that are increasingly appealing to corporate social responsibility.

\subsection{Value proposition}

By having a common problem and strategic objectives, the NGDOs studied converge on a similar value proposition. The main difference between them lies at the level of communication channels, fundraising approaches, as well as the locations where they focus.

If one Analyzes the value proposition in a deep way, it is identified that the biggest difference is in the communication channels, particularlywebsites, because there is an appreciable variation in quality and accessibility, ease of navigation, availability of information and speed of response to contacts.

The creation of value for the possible taxpayer is done through the dissemination of the reality object of intervention, using images and videos of local people, in general children, who despite living in strongly disadvantaged contexts, show great happiness for being able to go to school. Another approach is the presentation of results that give a perspective of effectiveness, success, and impact on development.

\subsection{Results/Impact}

The fifteen NGDOs studied present different indicators and results, but all consider efficiency, effectiveness, relevance, and impact. All of them show the evolution of school performance, the number of students and the number of actions carried out.

Regarding the evolution of school achievement, the most used indicators are the following: the literacy rate; the human development index; the average age of schooling; the average mortality/life expectancy rate in the first five years; family income; and poverty reduction.

In terms of the number of students, this indicator measures not only participants/influenced but also associated material assets, to go beyond the simple registration of students present through these: attendance rates; number of subscribers; school progression; average age; resources that are available per student; number of textbooks; number of scholarships available; school supplies, among others.

Regarding the number of actions performed, both school and extracurricular activities are reflected, making all the dynamics of the teaching-learning process. The number of schools are considered; the number of classes given per class; exchanges made; the number of meals served; the number of health examinations carried out; the number of sessions with the community; and the number of projects developed.

The local development resulting from the NGDOs studied is notorious and presents several stimulating results/impacts for beneficiaries, workers, and taxpayers. 


\subsection{Positive and negative externalities}

In positive externalities, we have the positive evolution of the local human development index.

Starting with the fight against poverty, by empowering the population, the existing economic activities undergo an upgrade process while creating space for other activities to develop. With this evolution, resources are freed up to invest more in health, which leads to increased hope and quality of life for populations. Another important aspect, related to local trade, is that it tends to increase in areas close to schools, creating a virtuous cycle.

In parallel to formal education, there is general and community education where moral and civic education is transmitted, favoring citizenship and the strengthening of democratic values. Well-structured education networks make it easier to implement national and international policies, measures, and actions, favoring and accelerating their evolution. There are also other factors associated with the education promoted by these NGDOs, such as the reduction of child labor and the development of talents.

On the side of negative externalities, we have the dependence of local communities on NGDOs. That makes it to local communities become vulnerable to the economic fluctuations of countries where sources of income are located and to changes in the interests of taxpayers. On the other hand, when they feel this support, national authorities relax their own efforts and investments, making it difficult to standardize education at the country level, creating and deepening differences between communities. Imbalances in local commercial activities may also arise, leading to the segregation of certain communities and giving rise to new communities in need.

\subsection{Mission}

Despite differences in strategies, main activities, internal organization, value proposition, projects, beneficiaries, customers, channels, cost structure, financial sustainability, problems, and solutions, it is possible to conclude that the mission of NGDOsin education in Mozambique is to promote the sectorto combat inequalities and increase the development of the country, seeking change for the better.

\section{Social business model Canvas of education NGDOs in Mozambique}

\subsection{Presentation of the proposed model}

Based on the empirical analysis developed in the previous section, we advanced with the following proposal of social business model Canvas for NGDOsin education in Mozambique: 
Figure 2 - Proposal of a social business model Canvas for NGDOsin education in Mozambique

\begin{tabular}{|c|c|c|c|c|c|c|}
\hline \multicolumn{6}{|c|}{$\begin{array}{l}\text { Mission } \\
\text { To promote education as a way to reduce inequalities specific to each locality and as a crucial factor for } \\
\text { progress in development. }\end{array}$} & \multirow[b]{2}{*}{$\begin{array}{l}\text { Positive } \\
\text { Externalities } \\
\text { - Empowerment of } \\
\text { the population } \\
\text { - Increase in } \\
\text { productivity } \\
\text { - Emergence of } \\
\text { new activities } \\
\text { - Stimulation of the } \\
\text { economies } \\
\text { - Improvements in } \\
\text { the health sector } \\
\text { - Democratic } \\
\text { communitarianism }\end{array}$} \\
\hline $\begin{array}{l}\text { Problem } \\
\text { Vulnerability } \\
\text { of } \\
\text { communities } \\
\text { due to low } \\
\text { level of } \\
\text { education. }\end{array}$ & $\begin{array}{l}\text { Key Activities } \\
\text { - Classes/training } \\
\text {-Community } \\
\text { Participation } \\
\text { - FundRaising } \\
\text { Secondary } \\
\text { Activities } \\
\text { - HealthandWellness } \\
\text { Note: Based on the } \\
\text { activities, define all } \\
\text { necessary resources }\end{array}$ & \multirow{2}{*}{\multicolumn{2}{|c|}{$\begin{array}{l}\text { Value Proposition } \\
\text { To convey the value } \\
\text { proposition in the most } \\
\text { impactful, visual and } \\
\text { attractive way, showing } \\
\text { that: } \\
\text { - Supporting the } \\
\text { development of realities } \\
\text { in need is accessible } \\
\text { - Everyone has the } \\
\text { possibility to contribute. } \\
\text { - The results are } \\
\text { noticeable, and the } \\
\text { more possibilities there } \\
\text { are, the more it } \\
\text { changes. }\end{array}$}} & $\begin{array}{l}\text { Relationship } \\
\text { with the } \\
\text { beneficiaries } \\
\text { Measuring their } \\
\text { interest and } \\
\text { evolution in order } \\
\text { to give a complete } \\
\text { andadapted } \\
\text { response } \\
\text { - A Priori } \\
\text { - During } \\
\text { - Posteriori }\end{array}$ & $\begin{array}{l}\text { Relationship } \\
\text { with taxpayers } \\
\text { Defining a strategy } \\
\text { to attract interest } \\
\text { and raisefunds } \\
\text { through: } \\
\text { - Solidary } \\
\text { Sponsors/Associat } \\
\text { es } \\
\text { - Donations } \\
\text { - Sales } \\
\text { - Events } \\
\text { - Funds andGrants }\end{array}$ & \\
\hline $\begin{array}{l}\text { Solution } \\
\text { To enable } \\
\text { access to } \\
\text { education for } \\
\text { all interested } \\
\text { members of } \\
\text { the target } \\
\text { audience }\end{array}$ & $\begin{array}{l}\text { Indicators/Results } \\
\text { - Number of Students } \\
\text { - Evolution of school } \\
\text { performance } \\
\text { - No. of actionstaken }\end{array}$ & & & $\begin{array}{l}\text { Communication } \\
\text { Channels } \\
\text { - Social Network } \\
\text { - WebSite } \\
\text { - Newsletter } \\
\text { Distribution } \\
\text { Channels } \\
\text { - International } \\
\text { - } \\
\text { NationalDistributio } \\
\text { n } \\
\text { - Local } \\
\text { Distribution } \\
\text { Sales Channels } \\
\text { - Direct } \\
\text { - Indirect }\end{array}$ & $\begin{array}{l}\text { Partners } \\
\text { To Detect all those } \\
\text { who can contribute } \\
\text { with goods and } \\
\text { services } \\
\text { - } \\
\text { Associations/Instit } \\
\text { utions } \\
\text { - Companies } \\
\text { - Publicentities } \\
\text { - Local partners }\end{array}$ & $\begin{array}{l}\text { Negative } \\
\text { Externalities } \\
\text { - Dependence of } \\
\text { the population on } \\
\text { the NGO } \\
\text { - Acting in thethird } \\
\text { sector } \\
\text { - Diversity of } \\
\text { means among } \\
\text { NGOs } \\
\text { - Possibility of } \\
\text { unbalancing the } \\
\text { economy } \\
\text { - Creation of }\end{array}$ \\
\hline \multicolumn{3}{|c|}{$\begin{array}{l}\text { CostStructure } \\
\text { To try to define fixed costs and variable costs } \\
\text { in order to reduce risksand look for partners } \\
\text { that can help reduce these. }\end{array}$} & \multicolumn{3}{|c|}{$\begin{array}{l}\text { Financial Sustainability } \\
\text { - Try to forecast costs so that at th eend of the year } \\
\text { expenses do not exceed revenues. } \\
\text { - Create a financial cushion to reducerisks }\end{array}$} & communities \\
\hline
\end{tabular}

Source: Own elaboration

\subsection{Model validation}

To validate the model built, a focus group techniquewas used, materialized in a panel of five qualified observers, purposely invited for this purpose and who were asked to comment on the adherence of the proposed model to the represented reality.

Three sessions were organized with a duration of 60 minutes each, with a 24-hour break in between. Given the current situation, the sessions took place virtually, using the digital platform Zoom.

The five experts were: 
- The representative of an educationNGDO working in Mozambique, outside the sample studied;

- A beneficiary of an education project of an NGDOin education working in Mozambique, at the age of 18 ;

- A client/contributor of an educationNGDO working in Mozambique;

- A partner of an NGDOin education working in Mozambique;

- A representative of the Ministry of Education and Human Development of Mozambique.

The model was tested according to the approach proposed by Fern (1982).

A discussion of the Mission Statement began. Although there was widespread agreement with it, the panelists suggested that the existing formulation be complemented with "human and economic" to specify the type of development targeted by education NGDOs.

The problem was then analyzed. There was a consensus in the panel on the importance of the elements formulated. However, it was emphasizedthat it was pertinentto add individuals and families and not restricting the problem to only to communities.

Regarding the key activities, the panel considered the activities put forwardas valid, but suggested adding a component relatedto the mobilization of volunteers. Considering the concrete reality of the country, and the specific experience of the panelists, volunteers are a determining component of the success of these organizations.

As for the Value Proposition, the panel found interesting the elements included in this section but suggested a reformulation to make clearer both the concept of value in a social business model and the scope of it.

As for the relationship with the beneficiaries, the panel considered the objectification in time steps to be particularly relevant. They proposed, however, that the beneficiaries should be specified, seeingno advantage ifthey wereonly implied.

The Relationship with Taxpayers block found unanimous support, and it was considered that it reflects the reality of the population studied.

In the Partners' analysis, the panel considered that the study carried out is correct, but that the list of the same should not be restricted and therefore it was suggested to be added "in particular, but not exclusively".

In the Channel block, the panel considered the presentation developed in three subgroups particularly relevant. Therefore, there was support for the formulation made of this block.

In the discussion of the elements placed in the Solution, the panel considered that the formulation developed was clear, but that it would be pertinent to join, at the end, "of each specific project and/or NGDO".

As for the Indicators/Results, the panel agreed with the chosen elements and discussed some others that could join those. However, this analysis did not exactly result in a 
concrete proposal for the combination of indicators, but only a recommendation to consider more alternatives.

The panel's assessment of financial sustainability is that, in the proposed model, the elements presented reflect a satisfactory response to the requirements of the model used, thus supporting the proposal made.

As far as the Cost Structure is regarded, the panel considered that there could be greater precision of this element, considering the information collected when assessing the data collected.

Regarding the appreciation of externalities, and starting with the positive ones, the panel suggested small improvements in detail that were promptly met and resubmitted to the same panel for final validation.

On negative externalities, minor changes and details were also suggested and it was stated that, overall, the proposal presented reflected the opinion of the elements of this focus group.

Therefore, the validated model presents the following configuration:

Figure 3 - Social Business Model Canvas for NGDOs in the field of education in Mozambique, after focus group validation

\begin{tabular}{|c|c|c|c|c|c|}
\hline \multicolumn{5}{|c|}{$\begin{array}{l}\text { Mission } \\
\text { To promote education as a way to reduce inequalities specific to each locality and as a crucial factor for } \\
\text { progress in terms of human and economic development. }\end{array}$} & \multirow[b]{2}{*}{$\begin{array}{l}\text { Positive } \\
\text { Externalities } \\
\text { - Capacity building } \\
\text { of the population in } \\
\text { key competencies } \\
\text { - Increased } \\
\text { productivity of the } \\
\text { Mozambican } \\
\text { economy } \\
\text { - Development of } \\
\text { new economic } \\
\text { activities } \\
\text { - Stimulation of } \\
\text { depressed economic } \\
\text { activities } \\
\text { - Improvements in } \\
\text { the health sector } \\
\text { - Increasing } \\
\text { democratic } \\
\text { communitarianism }\end{array}$} \\
\hline $\begin{array}{l}\text { Problem } \\
\text { Vulnerability of } \\
\text { individuals, } \\
\text { families and } \\
\text { communities } \\
\text { due to low } \\
\text { level of } \\
\text { education. }\end{array}$ & $\begin{array}{l}\text { Key Activities } \\
\text { - Classes/training } \\
\text { - Community } \\
\text { Participation } \\
\text { - Fundraising } \\
\text { - Mobilizing } \\
\text { Volunteers } \\
\text { Secondary } \\
\text { Activities } \\
\text { - Health and wellness } \\
\text { Note: Based on the } \\
\text { activities, define all } \\
\text { necessary resources }\end{array}$ & \multirow[t]{2}{*}{$\begin{array}{l}\text { Value } \\
\text { Proposition } \\
\text { The generic } \\
\text { benefit offered } \\
\text { is EDUCATION. } \\
\text { Hence the } \\
\text { following: } \\
\text { - Supporting } \\
\text { the } \\
\text { development } \\
\text { of realities in } \\
\text { need is } \\
\text { possible } \\
\text { - Everyone will } \\
\text { find an } \\
\text { intervention } \\
\text { space to give } \\
\text { their } \\
\text { contribution } \\
\text { - The results } \\
\text { are expressive } \\
\text { and clearly } \\
\text { measurable }\end{array}$} & $\begin{array}{l}\text { The beneficiaries } \\
\text { are individuals in } \\
\text { need of } \\
\text { education, by } \\
\text { age groups, } \\
\text { previous } \\
\text { qualification } \\
\text { levels and } \\
\text { geographical } \\
\text { areas } \\
\text { Measuring their } \\
\text { interest and } \\
\text { evolution in order } \\
\text { to provide a } \\
\text { complete and } \\
\text { adapted response } \\
\text { at the various } \\
\text { stages: } \\
\text { - A Priori } \\
\text { - During } \\
\text { - Posteriori }\end{array}$ & $\begin{array}{l}\text { Relationship with } \\
\text { taxpayers } \\
\text { To define a strategy to } \\
\text { attract interest and raise } \\
\text { funds through: } \\
\text { - Sponsors/Associates } \\
\text { - Donations } \\
\text { - Sales } \\
\text { - Events } \\
\text { - Funds and Grants }\end{array}$ & \\
\hline $\begin{array}{l}\text { Solution } \\
\text { Enable access } \\
\text { to education } \\
\text { for all those }\end{array}$ & $\begin{array}{l}\text { Indicators/Results } \\
\text { - Number of Students } \\
\text { - Evolution of school } \\
\text { performance }\end{array}$ & & $\begin{array}{l}\text { Communication } \\
\text { Channels } \\
\text { - Social Network }\end{array}$ & $\begin{array}{l}\text { Partners } \\
\text { Detect all those who can } \\
\text { contribute, namely with } \\
\text { goods and services, }\end{array}$ & $\begin{array}{l}\text { Negative } \\
\text { Externalities } \\
\text { - Dependence of }\end{array}$ \\
\hline
\end{tabular}




\begin{tabular}{|c|c|c|c|c|}
\hline $\begin{array}{l}\text { who are } \\
\text { interested } \\
\text { from the } \\
\text { target } \\
\text { audience of } \\
\text { each specific } \\
\text { project and/or } \\
\text { NGDO }\end{array}$ & - No. of actions taken & $\begin{array}{l}\text { - WebSite } \\
\text { - Newsletter } \\
\text { Distribution } \\
\text { Channels } \\
\text { - International } \\
\text { - National } \\
\text { Distribution } \\
\text { - Local Distribution } \\
\text { Sales Channels } \\
\text { - Direct } \\
\text { - Indirect }\end{array}$ & $\begin{array}{l}\text { though not exclusively. } \\
\text { - } \\
\text { Associations/Institutions } \\
\text { - Companies } \\
\text { - Public entities } \\
\text { - Local partners }\end{array}$ & $\begin{array}{l}\text { the population on } \\
\text { the NGO } \\
\text { - Acting in the third } \\
\text { sector } \\
\text { - Diversity of } \\
\text { means among } \\
\text { NGOs } \\
\text { - Possibility of } \\
\text { unbalancing the } \\
\text { economy } \\
\text { - Creation of } \\
\text { segregated } \\
\text { communities }\end{array}$ \\
\hline \multicolumn{2}{|c|}{$\begin{array}{l}\text { Cost Structure } \\
\text { To make a prior operational risk analysis to } \\
\text { determine the level of sustainable fixed costs, } \\
\text { trying, whenever possible, to replace them by } \\
\text { variable costs, since operational leverage is not } \\
\text { an objective of these organizations. }\end{array}$} & \multicolumn{2}{|c|}{$\begin{array}{l}\text { Financial Sustainability } \\
\text { - Try to forecast costs so that at the end of the year } \\
\text { expenses do not exceed revenues. } \\
\text { - Create a financial cushion to reduce risks }\end{array}$} & \\
\hline
\end{tabular}

Source: Own elaboration

\section{Conclusion}

The present work represents the first case identified in the literature of application and validation of the Social Business Model Canvas in NGDOs in Mozambique. The results achieved and described in this investigation support the pertinence of using the business model as a fundamental framework in the evaluation of the activities of third sector organizations.

Important implications can be drawn both for the management of these organizations and management of education in Mozambique. The participation of a representative of the Ministry of Education and Human Development of the country allowed considering this second vision in the validated model.

Finally, the main limitations were the fact that it was not possible to include further observations in our sample, or detailed data on the costs of the NGDOs assessed.

\section{References}

Agafonow, A., \& Donaldson, C. (2015). The economic rationale behind the social business model: A research agenda. Social Business 5(1), 5-16.

Aveni, A. (2018). 02.CANVAS SOCIAL: Tecnologia para modelar a missão e os impactos do terceiro setor. Revista JRG de Estudos Acadêmicos, I (2). 
Bendell, J (2000). Terms for Endearment: Business, NGOs and Sustainable Development. Oxfordshire: Routledge.

Calheiros A. A. (2003). Globalização e Desenvolvimento Local. Que futuro para os territórios desfavorecidos? p.7. Accessed on November 20, 2020. Available at: file://C:/Users/HP/Desktop/5335TM01000076519.pdf

Canestrino, R., Ćwiklicki, M., Di Nauta, P., \&Magliocca, P. (2019). Creating social value through entrepreneurship: the social business model of La Paranza. Kybernetes, 48(10), 2190-2216.

Carayannis, E. G., Grigoroudis, E., Stamati, D., \&Valvi, T. (2021). Social Business Model Innovation: A Quadruple/Quintuple Helix-Based Social Innovation Ecosystem. IEEE Transactions on Engineering Management, 68(1), 235-248.

CICLP (2014). Guia de avaliação. Gabinete de Avaliação e Auditoria.Accessed on November 20, 2020. Available at: https://www.oecd.org/derec/portugal/Guia_Avalia\%C3\%A7\%C3\%A30_V01.pdf.

Cohen, E. \& Franco, R. (1999). Avaliação de projetos sociais. Petrópolis: Vozes.

Coutinho, J. (2004). As ONGs: origens e (des)caminhos. Recherches Internationales, $\mathrm{n}^{\circ}$ 73.

Czinkota, M., Kaufmann, H. R., Basile, G., \& Ferri, M. A. (2020). For-Benefit Company (fBComp): An innovative social-business model. The Italian case. Journal of Business Research, 119, 377-387.

Defourny J., \& Nyssens M. (2008), Social enterprise in Europe: recent trends and developments. in Social Enterprise Journal, 4 (3).

Doherty, E. (2019). A Business Canvas for Social Business. Social Good Stuff. Accessed on October 30, 2020. Available at: http://socialgoodstuff.com/2019/11/a-businesscanvas-for-social-businesses/ .

Fern, E. F. (1982). The Use of Focus Groups for Idea Generation: The Effects of Group Size, Acquaintanceship, and Moderator on Response Quantity and Quality. Journal of Marketing Research, 19 (1), 1-13

Freire, P. (1987). Pedagogia do oprimido (17a ed.), p.87. Rio de Janeiro: Paz e Terra.

Freire, P. (1989a). Educadores de rua: Uma abordagem crítica. Bogotá: Editorial Gente Nueva

Freire, P. (1992b). Pedagogia da esperança. Rio de Janeiro: Paz e Terra.

Gauthier, C., Shanahan, G., Daudigeos, T., Ranville, A., \& Dey, P. (2020). Tackling economic exclusion through social business models: a typology. International Review of Applied Economics, 34(5), 588-606.

Gohn, M. G. (1997). Teorias dos movimentos sociais: paradigmas clássicos e contemporâneos. São Paulo: Loyola.

INE (2015). As instituições sem fins lucrativos em Moçambique: Resultados do segundo censo nacional (2014-2015). Accessed on November 20, 2020. Available at: ile:///C:/Users/pedro.cabrita/Downloads/Publicacao\%20CISFLU\%202014-2015.pdf 
Lugoboni., L., Ferrantly, M. \& Volpe, R. (2016). Organizational Performance: Practices Transfer in Multinational, NGORevista NAU Social, 7(12),125-142.

Maurya, A. (2010). Runing Lean: Iterate from Plan A to a Plan That Works. Califórnia: O'reilly.

Neto, C (2017). As Organizações da Sociedade Civil em Portugal. In Mafalda EiróGomes. Comunicação e Organizações da Sociedade Civil: conhecimento e reconhecimento. Lisboa Plataforma Portuguesa das ONGD e ESCS-IPL.

Osborne, S. P. (2008). The Third Sector in Europe: Prospects and Challenges. London: Routledge.

Osterwalder, A., (2004). The Business Model Ontology: A Proposition in a Design Science Approach. (D.Sc. Dissertation), Ecole des Hautes Etudes Commerciales de I'Université de Lausanne, Lausanne, France.

Osterwalder, A., \& Pigneur, Y. (2010). Business model generation: A handbook for visionaries, game changers, and challengers. New Jersey: Wiley.

Patrocínio, F. (2020). ONGs: impactos que vêm de dentro e de fora .Aupa, Jornalismo de impacto. Accessed on November 20, 2020. Available at: https://aupa.com.br/ongsimpactos-que-vem-de-dentro-e-de-fora/.

Plataforma Portuguesa das ONGD (2020). Áreas de Atuação. Accessed on November 20, 2020. Available at: https://www.plataformaongd.pt//o-nosso-trabalho/areas-deatuacao.

Resende, A. (2016). Modelagem de negócios de impacto Social. Cll Business News. Available at: https://collbusinessnews.com.br/modelagem-de-negocios-de-impactosocial/ (Accessed on November 20, 2020).

Roque-Amaro, R. (2003). Desenvolvimento - Um conceito ultrapassado ou em renovação? Da teoria à prática e da prática à teoria. Cadernos de Estudos Africanos, 4, 40-60.

Roque-Amaro, R. (2017). Desenvolvimento ou Pós-Desenvolvimento? DesEnvolvimento e... Noflay! Cadernos de Estudos Africanos, 34.

Sabatier, V., Medah, I., Augsdorfer, P., \& Maduekwe, A. (2017). Social business model design and implementation in developing countries: Learning from an affordable medicine developed in Burkina Faso. Journal of Management Development, 36(1), 4857.

Salvatore, V. (2004). A Racionalidade do 30 setor. In Voltolini, R., Terceiro Setor, Planejamento e Gestão (pp. 17-34). São Paulo: Senac.

SEA (Agência de empreendedores sociais), (2020). Curso intensivo online Empreendorismo e Inovação Social - SeaAgency.org, July 2020, Virtual.

Seers, D. (1969). The meaning of development.Accessed on November 20, 2020.

Available at

file://C:/Users/HP/Desktop/Seers\%20(1969)\%20The\%20Meaning\%20of\%20Develop ment.pdf. 
Singer P. (2002). Introdução à Economia Solidária. São Paulo: Fundação Perseu Abramo.

Singer, P. \& Brandt, V. C. (1980). São Paulo: o povo em movimento. Petrópolis: Vozes; São Paulo: Cebrap, 1980.

Sparviero, S. (2019). The Case for a Socially Oriented Business Model Canvas: The Social Enterprise Model Canvas. Journal of Social Entrepreneurship, 10(2), 232-251.

Spiess-Knafl, W., Mast, C., \& Jansen, S. A. (2015). On the nature of social business model innovation. Social Business, 5(2), 113-130.

Umar, A., Sasongko, A. H., Widyastuti, I. T. \& Christanti, Y. (2020). Improving the Social Enterprise-Based Business Performance from the Aspect of Social Business Model Canvas. International Journal of Entrepreneurship, 24(1). 